\title{
Yerli Dunaliella salina suşunda Büyüme ve Pigment Üretimi için Optimal Koşulların Merkezi Kompozit Tasarım Yöntemi Kullanılarak Belirlenmesi
}

\author{
Arzu Yıldırım ${ }^{1}$ \\ ${ }^{1}$ Ege Üniversitesi, Mühendislik Fakütesi, Biyomühendislik Bölümü, İzmir, Türkiye (ORCID: 0000-0001-9836-3181)
}

(İlk Geliş Tarihi 7 Kasım 2019 ve Kabul Tarihi 7 Aralık 2019)

(DOI: 10.31590/ejosat.649157)

\begin{abstract}
ATIF/REFERENCE: Yıldırım, A. (2019). Yerli Dunaliella salina suşunda Büyüme ve Pigment Üretimi için Optimal Koşulların
\end{abstract} Merkezi Kompozit Tasarım Yöntemi Kullanılarak Belirlenmesi. Avrupa Bilim ve Teknoloji Dergisi, (17), 874-880.

\begin{abstract}
$\ddot{O} \mathbf{z}$
Mikroalgler, sahip oldukları protein, lipid ve renkli pigmentler gibi doğal bileşikler sebebi ile biyoteknolojik uygulamalarda geniş bir kullanım alanı bulmaktadır. Yeşil algler sınıfına dahil olan ve yüksek tuz toleransı gösterebilen Dunaliella salina türü, doğal bir betakaroten kaynağı olması sebebi ile biyoteknolojik üretimlerde öne çıkan mikroalg türleri arasındadır. Yüksek tuzluluk, yüksek sıcaklık, yoğun ışık miktarı ya da besin kıtlığı gibi stres koşulları altında $D$. salina hücrelerinde beta-karoten birikimi gerçekleşmekte, ancak bu durum hücre büyümesini olumsuz etkilemektedir. $\mathrm{Bu}$ sebeple genellikle hazırlanan kültürlerde önce hücre büyümesinin teşvik edildiği, ardından stres koşulu uygulanarak pigment üretiminin artıııldığ iki fazlı üretim sistemi benimsenmiştir. Bu çalışmada yerel kaynaklardan izole edilen bir $D$. salina suşu için merkezi kompozit tasarım yönteminden faydalanılarak biyokütle artı̧ı ve hücre içi karotenoid birikimini, iki fazlı üretime gerek olmaksızın, eş zamanlı olarak teşvik edecek ortam koşullarının belirlenmesi amaçlanmıştır. Hücre içinde karotenoid birikimine sebep olan iki ortam bileşeni; tuz $(\mathrm{NaCl})$ ve nitrat $\left(\mathrm{KNO}_{3}\right)$, deney tasarımı için kullanılacak faktörler olarak seçilmiştir. Faktörlerin üç farklı düzeyinde gerçekleştirilen denemeler sonucunda ortamdaki tuz miktarının hem biyokütle artışı hem de karotenoid birikimi açısından birincil etmen olduğu belirlenmiştir. $D$. salina hücreleri için 1,75 $\mathrm{M} \mathrm{NaCl}$ ve $1,2 \mathrm{mM} \mathrm{KNO}_{3}$ içeren kültür ortamında biyokütlenin, ve paralel olarak hücre içi pigment miktarıın artışı için optimum koşul olarak belirlenmiş̧tir. Karotenoid birikimi, tuz konsantrasyonu açısından önemli ölçüde etkilenirken, kullanılan nitrat miktarının seçilen aralıkta daha düşük etki gösterdiği görülmüştür.
\end{abstract}

\section{Identification of Optimal Conditions for Growth and Pigment Production in indegenous Dunaliella salina strain Using Central Composite Design Method}

\begin{abstract}
Microalgae are widely used in biotechnological applications due to their natural compounds such as protein, lipid and colored pigments. Dunaliella salina, a green algae tolerant to high salt concentrations, is a natural source of beta-carotene, and therefore it is one of the microalgae species that is prominent in biotechnological productions. Beta-carotene accumulation occurs in $D$. salina cells under stress conditions such as high salinity, high temperature, intense light or nutrient scarcity, but these conditions also negatively affects the cell growth. A two-phase production system is usually applied to the cultures in which the cell growth is first promoted and then the pigment production is increased by applying the stress condition. In this study, it was aimed to determine the culture conditions that would simultaneously promote biomass growth and intracellular carotenoid accumulation without the need for two phase production by using the central composite design method for a Dunaliella salina strain isolated from local sources. Two media components that cause carotenoid accumulation in the cell; salt $(\mathrm{NaCl})$ and nitrate $\left(\mathrm{KNO}_{3}\right)$ were selected as the factors to be used for experimental design. As a result of the experiments carried out at three different levels of factors, it was determined that the amount of


salt in the medium was the primary factor in terms of both biomass increase and carotenoid accumulation. For $D$. salina cells, culture medium containing $1.75 \mathrm{M} \mathrm{NaCl}$ and $1.2 \mathrm{mM} \mathrm{KNO}_{3}$ was determined as the optimum condition for both increasing the amount of biomass and pigment accumulation in parallel. Carotenoid deposition was significantly affected by salt concentration, while the amount of nitrate used in the media was found to have a lower effect in the selected range.

Keywords: Biomass, Carotenoids, Central Composite Design, Dunaliella salina.

\section{Giriș}

Mikroalgler, bitki benzeri protistalar grubuna dahil, çoğu tek hücreli olan, genellikle sucul ortamlarda yaşamlarını sürdüren ökaryotik, fotosentetik organizmalardır (Khan ve ark., 2018). İçerdikleri protein, lipid ve pigmentler gibi doğal bileşikler sebebi ile biyoteknoloji alanında kullanımları son yıllarda dikkat çeken konular arasındadır (Osanai ve ark., 2017). Gıda ve yem amaçlı biyokütle üretiminden, biyodizel üretimi ve biyoremediasyon gibi ekolojik uygulamalara kadar pek çok alanda kullanımı olan mikroalgler, zengin biyoçeşitlilikleri sebebiyle çok çeşitli değerli bileşiğin üretimi için ümit vadeden doğal bir kaynak olarak görülmektedirler. (Pulz ve Gross, 2004).

Karotenoidler renkli pigmentler olup bitkiler, algler ve siyanobakterler gibi tüm fotosentetik canlllarda sentezlenmektedir. Yüksek antioksidan özelliğe sahip bu pigmentler genel olarak organizmaları serbest radikallere ve reaktif oksijen bileşiklerin zararlarına karşı korumaktadır (Fujisawa ve ark., 2009). Karotenoidler kozmetik ve gida endüstrisinde doğal renklendirici olarak (Diler ve Dilek, 2002), ayrıca hayvancılıkta ve deniz kültürlerinde yem olarak da geniş bir kullanım alanına sahiptir (Del Campo ve ark., 2007).

Dunaliella salina tuzlu sularda yaşamını sürdürebilen, yeşil algler sınıfına dahil bir mikroalg türüdür. Ortam koşullarında oluşan yüksek sıcaklık, yüksek tuzluluk ya da belli besin maddelerinin azalması Dunaliella hücrelerinin strese girmesine ve hücrenin bu stres koşullarından kendini korumasına yönelik olarak hücre içinde beta-karoten üretmesine neden olmaktadır. Beta-karoten hem turuncu renkli bir pigment olması, hem de yüksek antioksidan özellikleri sebebi ile biyoteknoloji alanında ilaç, boya ve yem sanayii gibi farklı alanlarda kullanılan değerli bir üründür. Bu bakımdan $D$. salina doğal beta-karoten üretimi için kullanılan önemli kaynaklardan birini oluşturmaktadır (Jin ve Melis, 2003; Hosseini Tafreshi ve Shariati, 2009).

Mikroalg hücreleri içinde pigment birikimine sebep olan stres koşulları hücre çoğalmasını olumsuz etkilemektedir. Bu problemi aşmak amacı ile yapılan çalışmalarda genellikle iki fazlı üretim yöntemi benimsenmiştir; ilk olarak üretim hücre büyümesi için gerekli optimum koşullarda gerçekleştirilerek hücre artışı sağlanmakta, ardından belli yoğunluğa ulaşan kültür ortamına seçilen stres koşulu uygulanarak hücre içinde pigment üretimi teşvik edilmektedir (Guerin ve ark., 2003; Benavente-Valdés ve ark., 2016; Chen ve ark., 2018 )

Tepki Yüzeyi Analizi metodu iki ya da daha fazla faktörün bir yanıt üzerine ne şekilde etki ettiğini belirlemek amacı ile kullanılan etkin bir yöntemdir. Bu yöntem ile çok sayıda deneme seti, malzeme ve zaman harcanmasına sebep olan her seferinde tek faktörün denendiği klasik uygulamalara göre daha az sayıda deneme seti ile istenilen yanıtlara ulaşılmaktadır (Khuri 2017, Değirmencioğlu ve Yazg1 2006). Merkezi Kompozit Tasarım metodu da bir Tepki Yüzeyi Analizi yöntemi olup, belirlenen sınırlar dahilinde seçilen faktörlerin maksimum, minimum ve orta noktaları kullanılarak oluşturulan deneme setleri yolu ile faktörlerin yanıt ile ilişkisini anlamaya imkan tanımaktadır.

Kültür ortamındaki nitrat ve tuz miktarı $D$. salina hücrelerinde pigment oluşumu teşvik eden iki önemli ortam bileşenidir (Marin ve ark., 1998; Pisal ve Lele, 2005; Morowvat ve Ghasemi, 2016). Bu çalışmada Ülkemizin yerel kaynaklarından izole edilen bir $D$. salina suşunda iki fazlı üretime gerek olmaksızın, ortam bileşenlerinden tuz ve nitrat konsantrasyonlarının hücre büyümesine paralel olarak karotenoid birikimini de teşvik edebileceği optimum aralığın, Merkezi Kompozit Tasarımı yöntemi kullanılarak belirlenmesi amaçlanmıştır.

\section{Materyal ve Metot}

\subsection{Dunaliella salina Stok Hazırlı̆̆ı ve Külttür Koşulları}

Çalışma materyali olarak, yerel kaynaklardan izole edilerek Ege Üniversitesi Kültür Koleksiyonu'na (EGE-MACC) dahil edilen Dunaliella salina suşu (EgeMacc-24) kullanılmıştır. Modifiye Johnson's ortamında kültür üretimi gerçekleştirilen (Johnson et al., 1968; Borowitzka, 1988). D. salina hücreleri $\sim 7 \times 10^{7}$ hücre $\mathrm{mL}^{-1}$ olana kadar çoğaltılarak stok kültür olarak kullanılmıştır. Stoktan 1 $\mathrm{mL}$ alınarak Merkezi Komposit Tasarım deney şeması doğrultusunda hazırlanarak 13 adet $100 \mathrm{~mL}$ ortam içeren erlenlere inoküle edilmiştir. Örnekler $25^{\circ} \mathrm{C}^{\prime} \mathrm{de} 30 \mu$ mol.photon $\mathrm{m}^{2} \cdot \mathrm{s}^{-1} 1$ ş̧ $\mathrm{k}$ şiddetinde beyaz florasan lamba ile sürekli olarak aydınlatılan, $110 \mathrm{rpm}$ hızında çalkalama gerçekleştiren bir çalkalayıcıya yerleştirilerek 7 gün boyunca büyümeleri takip edilmiştir. Ortam koşulları 7 gün boyunca sabit tutulmuş, böylelikle kültür ortamları üzerindeki tek stres koşulunun besin ortamı kompozisyonu olması sağlanmıştır.

\subsection{Merkezi Kompozit Tasarım Deney Düzeneği ve İstatistiksel Analizler}

Design Expert (version 7.0.0, Stat-Ease Inc., Minneapolis, MN) programı kullanılarak "iki faktörlü" "yüz merkezli" "Merkezi Kompozit Tasarım" metodu ile belirlenen ortam koşulları her örnek için ayrı ayrı hazırlanmıştır. Deneysel tasarım yöntemi ile, tanımlanan yüzey için minimum (-1) maksimum (+1) ve orta (0) olmak üzere her faktörün üç ayrı düzeyinin değerlendirildiği 13 ayrı deneme seti listelenmiştir (Tablo 1 ve Tablo 2). Seçilen düzlemin dışı hakkında da bilgi almaya yarayan "yıldız noktaları" deneme setine dahil edilmeyip, düzlem, faktörlerin maksimum ve minimum değerleri ile sınırlandırılmıştır. Faktörlerin, biyokütle artışı ve karotenoid birikimi üzerine anlamlı bir etkisi olup olmadığının belirlenmesi amacı ile ANOVA analizleri kullanılmıştır. 
Tablo 1. Merkezi Kompozit Deneysel Tasarımı Özeti

\begin{tabular}{ccccc}
\hline Faktör & $\begin{array}{c}\text { Madde İsmi ve } \\
\text { Birimi }\end{array}$ & \multicolumn{3}{c}{ Düzey Kodları } \\
\hline$A$ & $\mathrm{KNO3}(\mathrm{mM})$ & 1,20 & $\mathbf{0}$ & $\mathbf{+ 1}$ \\
\hline$B$ & $\mathrm{NaCl}(\mathrm{M})$ & 1,00 & 7,80 & 14,40 \\
& & & & \\
\hline
\end{tabular}

\subsection{Biyokütle ve Karotenoid Miktar Artışlarının Belirlenmesi}

\subsubsection{Hücre sayımı}

Hücre sayılarının belirlenmesi amacı ile Neubauer hemasitometre kullanılmıştır. Her örnekten $150 \mu \mathrm{L}$ alınarak, hareketli olan hücreleri sabitlemek amacı ile $1 \mu \mathrm{L}$ iyodin solusyonu eklenmiştir. Sayma kamarasına yayılan örnekler Olimpus CX21 ışık mikroskobu ile (Olympus Corporation, Tokyo, Japan) incelenerek sayma işlemi gerçekleştirilmiştir. Spesifik büyüme hızı $(\mu)$ ve kültürün ikilenme süresi (td) aşağıda verilen formüle göre belirlenmiştir.

$$
\begin{gathered}
\mu=\ln \left(\frac{\mathrm{N} 2-\mathrm{N} 1}{\mathrm{t} 2-\mathrm{t} 1}\right) \\
\mathrm{td}=\ln \left(\frac{\ln 2}{\mu}\right)
\end{gathered}
$$

Formülde; N1 ve N2, sırası ile t1 ve t2 zamanlarındaki hücre sayılarını ifade etmektedir.

\subsubsection{Optik Yoğunluk Ölçümleri}

Biyokütle artışının optik olarak belirlenmesi amacı ile Unicam Helios alpha UV-Vis spectrofotometre kullanılarak $680 \mathrm{~nm}$ dalga boyunda ölçümler gerçekleştirilmiştir.

\subsection{Toplam Karotenoid Analizi}

Toplam karotenoid miktarının belirlenmesi amacı ile pigment ekstraksiyonu gerçekleştirilmiştir. Her örnekten $2 \mathrm{~mL}$ alınarak 5000 rpm hızda \%80 aseton içinde tekrar dağılmaları sağlanan hücreler maksimum devirde 1 dakika vorteks yardımı ile çalkalanarak pigmentlerin çözünmesi sağlanmıştır. Tekrar $5000 \mathrm{rpm}$ hızda 5 dakika santrifüj uygulanan örneklerin renksiz hücre pelleti ile sıvı kısımları birbirinden ayrılmışır. Spektrofotometrik yöntem kullanılarak sıvı fazda pigment ölçümleri gerçekleştirilmiş ve Lichtenthaler ve Buschmann (2001) tarafından belirtilen formüller kullanılarak toplam karotenoid miktarı hesaplanmıştır.

\subsection{Kontrol Denemeleri:}

Merkezi Kompozit Tasarımı yöntemi sonucu elde edilen bulgular doğrultusunda iki ortam bileşeninin iki farklı düzeyi seçilerek, bir hafta süre ile iki kültür ortamının biyokütle artışı takibi ve pigment analizleri gerçekleştirilmiştir.

\section{Bulgular ve Tartışma}

\subsection{Merkezi Kompozit Tasarım Analizleri}

Merkezi Kompozit Tasarımı kullanılarak gerçekleştirilen denemeler sonucunda elde edilen veriler Tablo 2'de özetlenmiştir. Design Expert programı kullanılarak oluşturulan deneme setleri için gerçekleştirilen ANOVA analizleri sonucunda, "Biyokütle Artışı" ve "Toplam Karotenoid Miktarı"nın belirlenmesine yönelik oluşturulan model için anlamlı sonuçlar elde edilmiştir $(p<0,05)$. İki bağımsız değişken için oluşturulan iki modelin regresyon analizlerinden elde edilen $\mathrm{R}^{2}$ değerleri sırası ile 0,80 ve 0,70 olarak belirlenmiştir. Biyokütle artı̧̧ için quadratik bir eğilim gözlenirken, karotenoid miktarının daha çok lineer bir yapıda olduğu görülmektedir.

\subsection{Seçilen Faktörlerin Biyokütle Artışı ve Toplam Karotenoid Miktarına Etkisi}

Biyokütle artışı ve karotenoid birikimine etkileri incelenmek üzere seçilen tuz $(\mathrm{NaCl})$ ve nitrat $\left(\mathrm{KNO}_{3}\right)$ bileşenleri içerisinde, tuz miktarının her iki yanıt için de daha etkin bir faktör olduğu belirlenmiş̧tir. Tuz miktarının 2,5 M ve daha altı konsantrasyonda kullanılmasının biyokütle artışını teşvik ettiği gözlenmiş, ancak 2,5 M üzerinde bir tuzluluk oranının biyokütle artışını ve buna paralel olarak birim hacimdeki karotenoid birikimini olumsuz etkilediği görülmüştür (Şekil 1 ve 2).

Ortamdaki tuz ve nitrat bileşenleri arasında belirgin bir interaksiyon gözlenmemişse de düşük nitrat konsantrasyonlarında $(1,2 \mathrm{mM})$ tuz toleransının 3 M'ın üzerine çıkabildiği görülmüştür. 2,5 M tuz konsantrasyonunun daha altındaki değerler için ortamdaki nitrat miktarının biyokütle artışıı ve karotenoid birikimini farklı şekillerde etkilediği belirlenmiştir. Aynı tuzluluk seviyesinde nitratın düşük ve yüksek konsantrasyonları biyokütle artışını teşvik ederken (Şekil 1), karotenoid miktarı kısmen eşit kalmakla birlikte nitrat konsantrasyonun artması doğrultusunda azalma eğilimi göstermektedir (Şekil 2). 
Genel olarak D. salina türleri $0,05 \mathrm{M}$ ile 5,5 M arasında değişen tuz konsantrasyonlarını tolere edebilmektedirler (Chen ve Jiang 2009). Daha önce, Türkiye'de Tuz Gölü'nden izole edilen bir Dunaliella sp. suşu için yapılan denemelerde en yüksek hücre konsantrasyonu ve beta-caroten birikiminin \%20'lik tuz konsantrasyonunda (yaklaşık 3,5 M) elde edildiği bildirilmektedir (Çelekli ve Dönmez 2006). Ancak genel olarak yüksek oranda tuz toleransı gösterebilen D. salina suşları için optimum tuz konsantrasyonu 100$150 \mathrm{~g} \mathrm{~L}^{-1}$ (yaklaşık 1,5-2,5 M) olarak ifade edilmektedir (Oren 2014). Çalışmamızda, seçilen en düşük nitrat konsantrasyonu için EgeMacc-24 D. salina suşunun 3,5 M tuz konsantrasyonlarına tolerans gösterdiği, ancak optimum biyokütle artışının 1,5-2,5 M arasında gerçekleştiği belirlenmiştir.

Tablo 2. Merkezi Kompozit Deneysel Tasarımı Özeti

\begin{tabular}{ccccc}
\hline $\begin{array}{c}\text { Deneme } \\
\text { Seti } \\
N o\end{array}$ & $\begin{array}{c}\mathrm{KNO}_{3} \\
m M\end{array}$ & $\begin{array}{c}\mathrm{NaCl} \\
M\end{array}$ & $\begin{array}{c}\text { Biyokütle Artı̧1 } \\
\text { OD680 }\end{array}$ & $\begin{array}{c}\text { Toplam Karotenoid } \\
\text { Miktar1 } \\
\mu g / m L\end{array}$ \\
\hline 1 & 14,4 & 1 & 0,285 & 4,631 \\
2 & 7,8 & 2,5 & 0,196 & 3,608 \\
3 & 14,4 & 4 & 0,103 & 2,054 \\
4 & 7,8 & 4 & 0,132 & 2,696 \\
5 & 1,2 & 1 & 0,293 & 5,033 \\
6 & 1,2 & 2,5 & 0,288 & 3,620 \\
7 & 14,4 & 2,5 & 0,278 & 4,043 \\
8 & 7,8 & 1 & 0,223 & 3,790 \\
9 & 7,8 & 2,5 & 0,289 & 5,143 \\
10 & 7,8 & 2,5 & 0,196 & 4,091 \\
11 & 7,8 & 2,5 & 0,265 & 4,656 \\
12 & 1,2 & 4 & 0,157 & 2,715 \\
13 & 7,8 & 2,5 & 0,197 & 3,649 \\
\hline
\end{tabular}

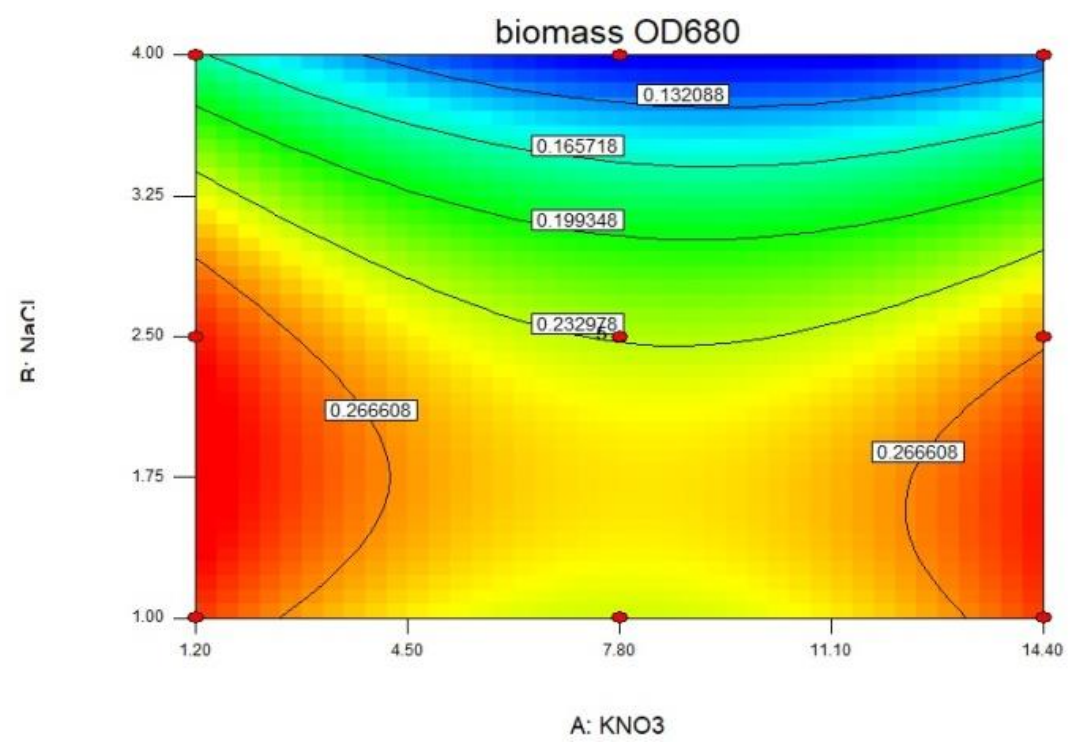

Şekil 1: Seçilen yüzey aralıklarında, tuz ve nitrat konsantrasyonlarının biyokütle artışına etkisi 


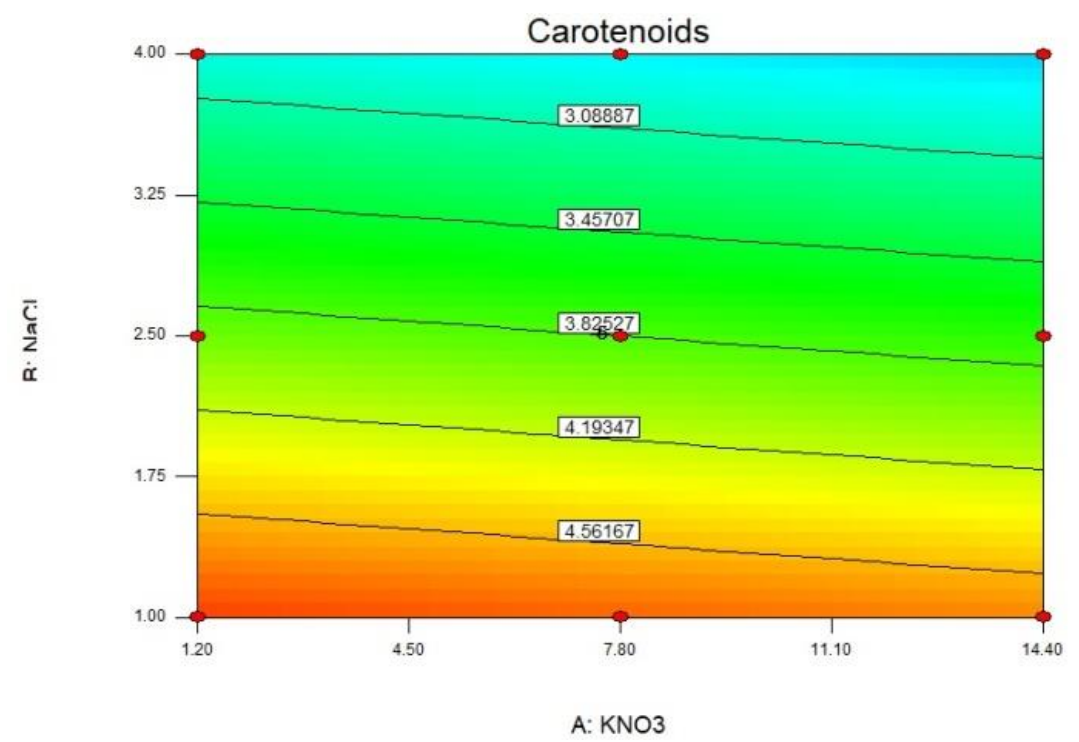

Şekil 2: Seçilen yüzey aralıklarında, tuz ve nitrat konsantrasyonlarının karotenoid birikimine etkisi

\subsection{Kontrol Denemeleri}

Biyokütle ve karotenoid birikiminin aynı ortamda eş zamanlı olarak teşvik edilmesine yönelik optimum tuz ve nitrat seviyelerinin belirlenmesi amacı doğrultusunda, merkezi kompozit tasarım metodunda elde edilen veriler ışı̆̆ında iki farklı yüzey noktası seçilerek kontrol denemeleri gerçekleştirilmiştir. Tablo 3'de D1 ve D7 olarak belirtilen ortamlar hazırlanarak D. salina hücreleri 1 hafta süre ile kültüre edilerek, hücre sayımları ve karotenoid analizleri gerçekleştirilmiş ve kültürlerin ikilenme süreleri hesaplanmıştır.

Tablo 3: Kontrol ortamlarında kullanılan ortam bileşenleri ve ikilenme süreleri (td)

\begin{tabular}{cccc}
\hline & KNO3 (mM) & NaCl (M) & $t \boldsymbol{t d}($ gün $)$ \\
\hline D1 & 1,2 & 1,75 & 3,61 \\
D7 & 7,8 & 1,5 & 3,98
\end{tabular}

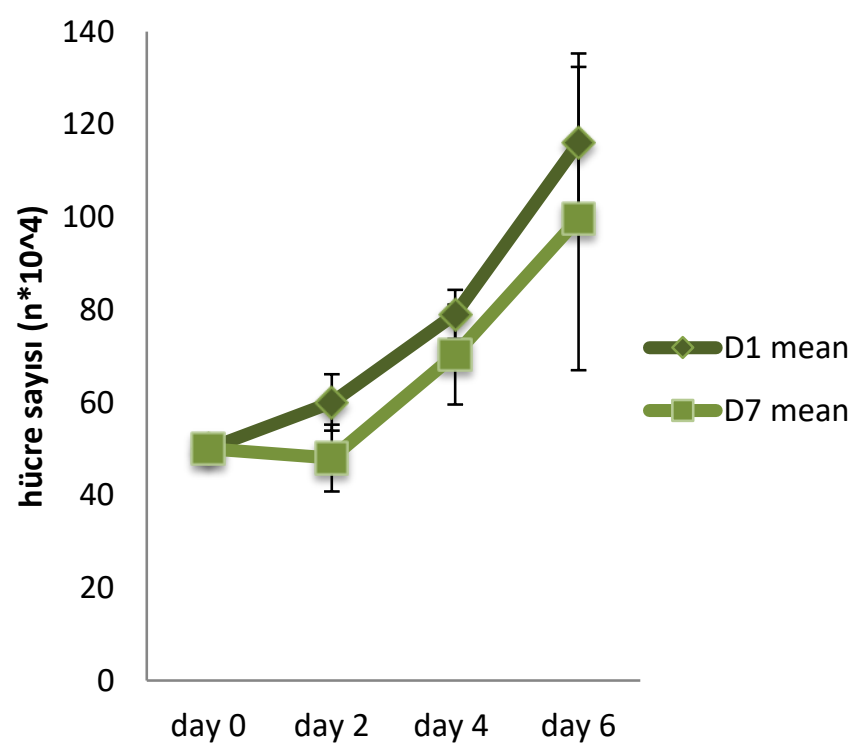

Grafik 1: D1 ve D7 ortamlarında geliştirilen kültürler için $m L$ 'deki hücre sayısı artışı

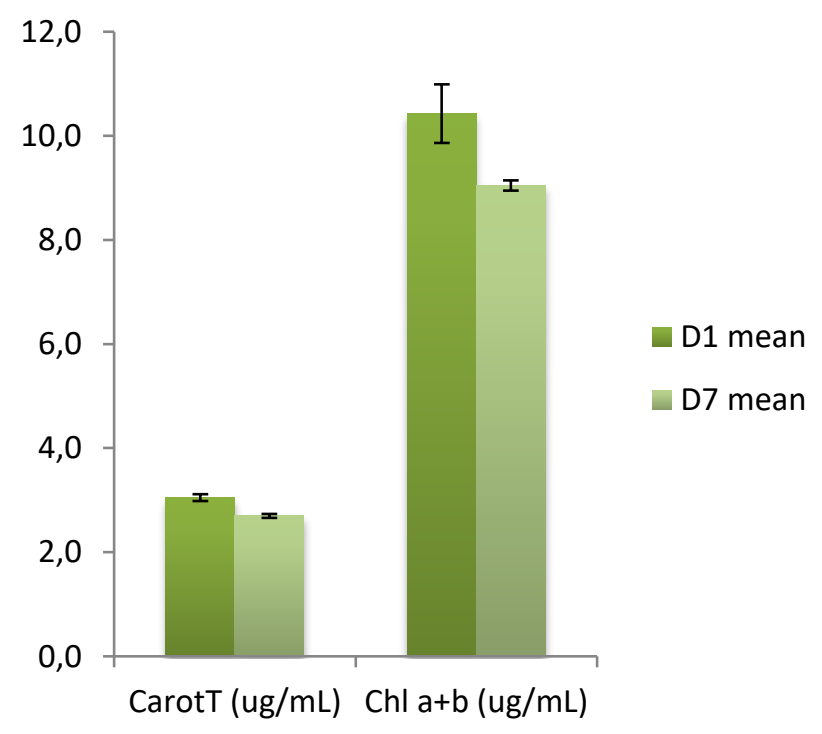

Grafik 2: D1 ve D7 ortamlarında geliştirilen kültürler için mL'deki karotenid ve klorofil miktar artışı 
Kontrol denemeleri sonucunda elde edilen veriler Grafik 1 ve 2'de özetlenmiştir. Seçilen iki ortam karşılaştırıldığında, her iki özellik için de birbirine yakın değer elde edilmiş olmasına rağmen, $1,2 \mathrm{mM} \mathrm{KNO}_{3}$ ve $1,75 \mathrm{M} \mathrm{NaCl}$ içeren D1 ortamının, hem biyokütle artışı hem de karotenoid birikimi açısından daha olumlu sonuçlar verdiği gözlenmiştir.

\section{Sonuç}

Dunaliella salina, doğal beta-karoten kaynağı olması sebebi ile yeşil mikroalg türleri içiresinde ayrı bir öneme sahiptir. Hücrenin potansiyelinden maksimum seviyede faydalanmak açısından hem kültürün gelişim hızı, hem de hücrenin pigment üretim miktarı, üretimi etkileyebilecek önemli iki unsur olarak öne çıkmaktadır.

Ortam parametrelerinin istenilen kültür özelliklerine etkisini incelemek üzere klasik olarak uygulanan deneme setleri yerine, yüzey analiz yöntemleri kullanılarak yapılan taramalar, hem uygulanacak deney sayısı hem de deney için harcanacak malzeme ve zaman açısından avantaj sağlamaktadır.

Bir yüzey yanıt analiz yöntemi olam Merkezi Kompozit Tasarım Metodu kullanılarak gerçekleştirilen denemeler sonucunda yerel kaynaklardan elde edilen bir $D$. salina suşu için iki önemli ortam bileşeninin biyokütle artışı ve pigment birikimine etkisi incelenmiş ve $1,75 \mathrm{M} \mathrm{NaCl}$ ve $1,2 \mathrm{mM} \mathrm{KNO}_{3}$ kullanılan kültür ortamında her iki özelliğin pararlel olarak teşvik edildiği belirlenmiştir. İncelenen iki ortam bileşeninin seçilen aralıkları için ortamdaki tuz miktarının, ortama eklenen potasyum miktarından daha etkili olduğu gözlenmiştir. Belirlenen değerlerde hazırlanan kültür ortamı kullanılarak geliş̧tirilen $D$. salina kültüründe üretim sisteminin değiştirilmesine veya ikincil bir stres koşulu uygulanmasına gerek olmaksızın etkin karotenoid üretiminin sağlanacağı düşünülmektedir.

\section{Kaynakça}

Benavente-Valdés J.R., Aguilar C., Contreras-Esquivel J.C., Méndez-Zavala A., Montañez A., (2016). Strategies to enhance the production of photosynthetic pigments and lipids in chlorophycae species. Biotechnology Reports, 10: 117-125 DOI: 10.1016/j.btre.2016.04.001

Borowitzka, M. A. (1988). Algal growth media and sources of cultures, In: Borowitzka M.A. ve Borowitzka L.J. (eds.), Micro-algal Biotechnology. Cambridge University Press: Cambridge. pp. 456-465, https://doi.org/10.1002/jctb.280470214

Borowitzka M.A. (1988). Vitamins and fine chemicals. In: Borowitzka M.A. ve Borowitzka L.J. (eds), Micro-algal Biotechnology. CambridgeUniversity Press, Cambridge, 153-196. https://doi.org/10.1002/jctb.280470214

Chen C.Y., Lu I.C., Nagarajan D., Chang C.H., Ng I.S., Lee D.J., Chang J.S. (2018). A highly efficient two-stage cultivation strategy for lutein production using heterotrophic culture of Chlorella sorokiniana MB-1-M12. Bioresource Technology, Volume 253: 141-147. https://doi.org/10.1016/j.biortech.2018.01.027

Chen H. ve Jiang J.G., (2009). Osmotic responses of Dunaliella to the changes of salinity. J Cell Physiol. 219(2):251-8. DOI: $10.1002 / j \mathrm{jcp} .21715$

Çelekli A. ve Dönmez G. (2006). Effect of pH, light intensity, salt and nitrogen concentrations on growth and b-carotene accumulation by a new isolate of Dunaliella sp. World Journal of Microbiology \& Biotechnology. 22: 183-189. DOI: 10.1007/s11274-0059017-0

Değirmencioğlu A. ve Yazgı A. (2006). Tepki Yüzeyleri Metodolojisi "Optimizasyon Esaslı Çalışmalara İlişkin Teorik Esaslar ve Tarımsal Mekanizasyon Uygulamaları" . Tarım Makinaları Bilimi Dergisi 2(2): 111-115.

Del Campo J.A., Garcia-Gonzales M., Guerrero M.G. (2007). Outdoor cultivation of microalgae for carotenoid production: current state and perspectives. Appl Microbiol Biotechnol 74: 1163-1174. DOI: 10.1007/s00253-007-0844-9

Diler, İ., Dilek, K., (2002). Significance of Pigmentation and Use in Aquaculture. Turkish Journal of Fisheries and Aquatic Sciences 2: $97-99$

Fujisawa, M., Takita, E., Harada, H., Sakurai, N., Suzuki, H., Ohyama,K., Shibata, D., Misawa, N., (2009). Pathway engineering of Brassica napus seeds using multiplekey enzyme genes involved in ketocarotenoid formation. J Exp Bot, 60(4):1319-32. DOI: 10.1093/jxb/erp006.

Guerin M., Huntley M.E., Olaizola M. (2003). Haematococcus astaxanthin: applications for human health and nutrition. Trends Biotechnol. 21:210-216. https://doi.org/10.1016/S0167-7799(03)00078-7

Hosseini Tafreshi A. ve Shariati M. (2009). Dunaliella biotechnology: methods and applications. Journal of Applied Microbiology, 107: 14-35. https://doi.org/10.1111/j.1365-2672.2009.04153.x

Jin E.S. ve Melis A. (2003). Microalgal Biotechnology: Carotenoid production by the green algae Dunaliella salina. Biotechnology and Bioprocess Engineering. 8: 331-337. DOI: 10.1007/BF02949276

Johnson, M.K., Johnson, E.J, Mac Elroy, R.D., Speer, H.L. and Bruff, B.S. (1968). Effects of salts on the halophilic alga Dunaliella viridis. J. Bacteriology 95: 1461-1468.

Khan M.I., Shin J.H., Kim J.D. (2018). The promising future of microalgae: current status, challenges, and optimization of a sustainable and renewable industry for biofuels, feed, and other products. Microb. Cell Fact. 17:36 https://doi.org/10.1186/s12934-018-0879-x

Khuri A.I., (2017). A General Overview of Response Surface Methodology. Biom Biostat Int J 5(3): 00133. DOI: 10.15406/bbij.2017.05.00133 
Lichtenthaler HK, Buschmann C (2001). Chlorophylls and Carotenoids: Measurement and Characterization by UV-VIS Spectroscopy. In: Current Protocols in Food Analytical Chemistry. New York, NY, USA: John Wiley and Sons, Inc. F4.3.1-F4.3.8. https://doi.org/10.1002/0471142913.faf0403s01

Marin N., Morales F., Lodeiros C., Tamigneaux E. (1998). Effect of nitrate concentration on growth and pigment synthesis of Dunaliella salina cultivated under low illumination and preadapted to different salinities. Journal of Applied Phycology 10: 405411, 1998. DOI: 10.1023/A:1008017928651

Morowvat M.H. ve Ghasemi Y. (2016). Culture medium optimization for enhanced $\beta$-carotene and biomass production by Dunaliella salina in mixotrophic culture Biocatalysis and Agricultural Biotechnology 7: 217-223. https://doi.org/10.1016/j.bcab.2016.06.008

Oren A., (2014). The ecology of Dunaliella in high-salt environments. Journal of Biological Research-Thessaloniki , 21:23, DOI: 10.1186/s40709-014-0023-y

Osanai T., Park Y.I., Yuki Nakamura Y. (2017). Editorial: Biotechnology of Microalgae, Based on Molecular Biology and Biochemistry of Eukaryotic Algae and Cyanobacteria. Front. Microbiol. 8:118. DOI: 10.3389/fmicb.2017.00118

Pisal D.S. ve Lele S.S. (2005). Carotenoid production from microalga, Dunaliella salina. Indian Journal of Biotechnology 4: 476-483.

Pulz, O. ve Gross, W., (2004). Valuable products from biotechnology of microalgae. Appl. Microbiol. Biotechnol. 65(6): 635-648. DOI: $10.1007 / \mathrm{s} 00253-004-1647-\mathrm{x}$ 